\title{
PROMOTED HYDROLYSIS OF SOME ORGANOPHOSPHATE ESTERS USING SUPPORTED [Cu(tmen) $\left.\mathrm{OH}\left(\mathrm{OH}_{2}\right)\right]^{+}$
}

\author{
Murat ERDEM * \\ Department of Chemistry, Faculty of Science, Anadolu University, Eskişehir, Turkey
}

\begin{abstract}
In this study, tetramethylethylenediamine copper(II) complex $\left(\mathrm{Cu}(\mathrm{tmen}) \mathrm{Cl}_{2}\right)$ was synthesized and natural clay smectite and synthetic Dowex-50WX8 resin containing $\mathrm{Cu}(\mathrm{tmen})(\mathrm{OH})\left(\mathrm{OH}_{2}\right)^{+}$were prepared via ion exchange process in aqueous solution. Dowex- and smectite-supported $\mathrm{Cu}(\mathrm{tmen})(\mathrm{OH})\left(\mathrm{OH}_{2}\right)^{+}$were used as a supported catalyst in the hydrolysis reactions of organophosphate compounds of diethyl-p-nitrophenyl phosphate and $p$-nitrophenyl diphenyl phosphate at different $\mathrm{pH}$ values. Scanning electron microscope attached with energy dispersive X-ray dedector and surface area analyzer were used for the characterization of the supported catalysts. The efficiency of these supported catalysts was evaluated in accordance with pseudo-first-order and Michaelis-Menten enzyme kinetic models. The amount of copper(II) complex in Dowex-supported catalyst was higher than that of smectite-supported one $(1.36 \mathrm{mmol} / \mathrm{g}$ and $0.88 \mathrm{mmol} / \mathrm{g}$, respectively) and the higher efficiency was obtained when Dowex-supported catalyst was employed in all of the hydrolysis reactions. 222 and 114-fold increasing in pseudo-first-order rate constants compared to the reactions without supported catalyst were observed for the hydrolysis of diethyl-p-nitrophenyl phosphate at $\mathrm{pH} 8.0$ in the presence of Dowex-supported and smectite-supported catalysts.
\end{abstract}

Keywords: Dowex-50WX8, Smectite, Tetramethylethylenediamine copper(II) complex, Diethyl-p-nitrophenyl phosphate, $p$-Nitrophenyl diphenyl phosphate

\section{INTRODUCTION}

Organophosphate esters have been used as insecticides for many years to protect the crops and animals from harmful effects of insects. Their toxicity and persistence in the environment is causing short and long term health problems in humans. Parallel to insecticide development, appreciation of their potential lethality also led to consideration of their use as chemical warfare agents. Although modern chemical weapons (known as nerve agents) have been used in limited circumstances, large quantities of agents such as sarin, soman and tabun are still stockpiled in a number of countries around the world, and their destruction requires the use of environmentally friendly processes. Both nerve agents and insecticides act as an inhibitor for enzyme acetylcholinesterase which is responsible for regulating the concentration of the neurotransmitter acetylcholine [1-5].

Although the use of organophospahate esters as insecticide or herbicide is important to the agricultural industry, their extensive use can also lead to poisoning due to the exposure of large numbers of people worldwide. Moreover, their accumulation in the environment is a recognized ecological threat with harmful effects on living species [6]. Despite the intense research during the second half of the last century, the detoxification or decontamination of organophosphate esters is still a serious problem. Thus, many researchers have been attracted to develop phosphorolytic decontaminants for the cleavage of organophosphate ester compounds. For this purpose, many detoxification agents such as metal complexes and metallomicelles [7-11], $o$-iodosylcarboxylates and polymer-supported $o$ iodosylcarboxylates [12-16], $\alpha$-effect nucleophiles [17, 18], biological catalysts $[19,20]$, substrate imprinted polymers $[21,22]$ have been developed.

*Corresponding Author: merdem@anadolu.edu.tr 
There has been considerable interest in the area of metal-hydroxo nucleophiles and their role in promoting the hydrolysis of organophosphate esters. Metal ions may simultaneously act as nucleophiles by providing a metal-hydroxide to perform an intramolecular attack [23]. The tetramethylethylenediamine copper(II) complex, $\left[\mathrm{Cu}(\mathrm{tmen})(\mathrm{OH})\left(\mathrm{OH}_{2}\right)\right]^{+}$, was one of the first metal complexes used for the hydrolysis of organophospahates [24]. A drawback of these homogeneous catalyses is the impossibility to recover and recycle the catalyst while the supported catalyst can easily be isolated and recovered by precipitation and filtration. Immobilization of the catalysts on an insoluble matrix can provide a simple solution to this problem. Polymer-supported metals or metal complexes have been widely used heterogeneous catalysts active in the cleavage of phosphoric esters for last years. Hartshorn and coworkers [25] synthesized $\mathrm{N}$-vinylbenzyl-based polymeric supports containing $\mathrm{Cu}(\mathrm{II})$ 1,4,7-triazacyclononane complex and examined their catalytic performances towards methyl parathion $(\mathrm{MeP})$ and bis-(4-nitrophenyl) phosphate (BNPP). The hydrolysis rates obtained with their catalysts are among the higher reported for the polymer-supported hydrolysis of MeP and BNPP. In another study, a series of polymer-supported bidentate amine $\mathrm{Cu}(\mathrm{II})$ complexes were obtained and hydrolytic decomposition of the nerve agent, sarin, was studied [26]. Styrene- and (meth)acrylate-based linear polymers, poly(vinylbenzyl chloride)- and methacrylate-based macroporous resins, 8-hydroxyquinoline containing methacrylate resins, methacrylate- and acrylate-based hydrogels were selected as support to attach complexes. Bukowski et al. [27] prepared a family of copolymeric hydrogels containing vinylimidazole, acrylamide and $N, N^{\prime}$-methylenebisacrylamide to bind $\mathrm{Cu}(\mathrm{II})$ ions. The hydrolysis activity of obtained $\mathrm{Cu}$ (II)-loaded hydrogels towards bis(3-nitrophenyl)phosphate was five orders of magnitude greater than the uncatalyzed reaction. Mersal and Ibrahim [7] investigated the hydrolysis of parathion catalyzed with both $\mathrm{Zn}$ (II) and $\mathrm{Cu}$ (II) complexes of tris(2-benzylaminoethyl)amine (BzTren) and the kinetic results indicated that $\mathrm{Cu}(\mathrm{II})$ complex is more active than $\mathrm{Zn}(\mathrm{II})-\mathrm{BzTren}$.

Although the organophosphate hydrolysis promoted by $\left[\mathrm{Cu}(\mathrm{tmen})(\mathrm{OH})\left(\mathrm{OH}_{2}\right)\right]^{+}$have been reported, studies on efficiency of smectite- and Dowex 50WX8-supported $\left[\mathrm{Cu}(\mathrm{tmen})(\mathrm{OH})\left(\mathrm{OH}_{2}\right)\right]^{+}$are not available in the literature. In this study, supported $\mathrm{Cu}(\mathrm{tmen})(\mathrm{OH})\left(\mathrm{OH}_{2}\right)^{+}$were prepared and used as supported catalysts for the hydrolysis of model compounds diethyl-p-nitrophenyl phosphate (paraoxon, PO) and $p$-nitrophenyl diphenyl phosphate (PNPDPP) in basic aqueous solutions. A natural clay smectite $(\mathrm{Sm})$ and cation exchange resin Dowex-50WX8 (Dw) were used as support. The effects of $\mathrm{pH}$ and temperature on the efficiency of the supported catalysts were investigated.

\section{EXPERIMENTAL}

\subsection{Materials}

Paraoxon, Dowex-50WX8 (Diethenyl-benzene polymer with ethenylbenzene and ethenylethylbenzene, sulfonated), $N, N, N^{\prime}, N^{\prime}$-tetramethylethylenediamine, TAPS buffer compound, $\mathrm{CuCl}_{2} \cdot 2 \mathrm{H}_{2} \mathrm{O}$, methanol and diethyl ether were purchased from Sigma-Aldrich (USA). PNPDPP was synthesized according to the literature [28].

\subsection{Synthesis of Copper(II) Complex of $N, N, N^{\prime}, N^{\prime}$-Tetramethylethylenediamine}

Synthesis of copper complex of $N, N, N^{\prime}, N^{\prime}$-tetramethylethylenediamine $\left(\mathrm{Cu}(\mathrm{tmen}) \mathrm{Cl}_{2}\right)$ was carried out as follows: A solution of $N, N, N^{\prime}, N^{\prime}$-tetramethylethylenediamine (tmen) was prepared via dissolution of $2.90 \mathrm{~g}$ of the ligand in ethanol $(80 \mathrm{~mL})$ then a solution of $\mathrm{CuCl}_{2} \cdot 2 \mathrm{H}_{2} \mathrm{O}(5.1 \mathrm{~g})$ in methanol $(200 \mathrm{~mL})$ was added dropwise with stirring to the solution of tmen. The solution was evaporated to the total volume of $150 \mathrm{~mL}$. After crystallization of the dark blue complex, it was filtered off and recrystallized from methanol-diethyl ether and dried in a vacuum oven at $40^{\circ} \mathrm{C} .\left[\mathrm{Cu}(\mathrm{tmen}) \mathrm{Cl}_{2}\right]$ was characterized with elemental analysis. Elemental analysis: Calculated for $\mathrm{C}_{6} \mathrm{H}_{16} \mathrm{~N}_{2} \mathrm{Cl}_{2} \mathrm{Cu}$ (FW 250.66): C, 28.75; H, 6.43; $\mathrm{N}, 11.18$. Found: $\mathrm{C}, 28.54 ; \mathrm{H}, 6.51 ; \mathrm{N}, 11.12$. The chemical structure of the complex is given in Figure 1 . 


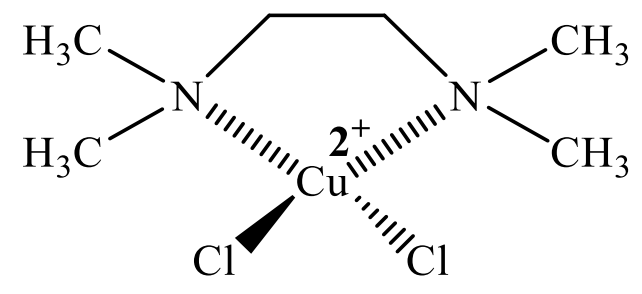

Figure 1. The chemical structure of $\left[\mathrm{Cu}(\mathrm{tmen}) \mathrm{Cl}_{2}\right]$

\subsection{Preparation of Supported Catalysts}

The supported catalysts were prepared by means of ion exchange process. Before the exchange, Dw was washed with $0.1 \mathrm{M} \mathrm{HCl}$ solution to eliminate undesired impurities. Thereafter, Dw was washed several times with double distilled water to remove all the excess acid and chloride anion.

A certain amount of dry support (dried a day at $50{ }^{\circ} \mathrm{C}$ in a vacuum oven) was added to the aqueous solution of $\mathrm{Cu}(\mathrm{tmen})(\mathrm{OH})\left(\mathrm{OH}_{2}\right)^{+}$. After stirring a period of $5 \mathrm{~h}$ at room temperature, the solid was filtered and washed with double distilled water several times. Then the solid was dried in a vacuum oven at $50{ }^{\circ} \mathrm{C}$ overnight. Elemental analysis was done to determine the amount of the complex per gram of dry solid. Dowex- and smectite-supported $\mathrm{Cu}(\mathrm{tmen})(\mathrm{OH})\left(\mathrm{OH}_{2}\right)^{+}$were named as $\mathrm{Dw}-\mathrm{Cu}$ and $\mathrm{Sm}-\mathrm{Cu}$, respectively. Some physical and quantitative characteristics of the supported catalysts are given in Table 1.

Table 1. Some physical and quantitative characteristics of the supports and supported catalysts

\begin{tabular}{|c|c|c|c|c|}
\hline Parameters & Dw & $\mathbf{S m}$ & Dw-Cu & $\mathrm{Sm}-\mathrm{Cu}$ \\
\hline BET surface area $\left(\mathrm{m}^{2} \mathrm{~g}^{-1}\right)$ & 7.08 & 80.33 & 12.51 & 94.60 \\
\hline Micropore area $\left(\mathrm{m}^{2} \mathrm{~g}^{-1}\right)^{\mathrm{a}}$ & 0 & 8.20 & 0 & 41.17 \\
\hline External surface area $\left(\mathrm{m}^{2} \mathrm{~g}^{-1}\right)^{\mathrm{a}}$ & 7.08 & 72.13 & 12.51 & 53.43 \\
\hline Total pore volume $\left(\mathrm{cc} \mathrm{g}^{-1}\right)^{\mathrm{b}}$ & $7.20 \times 10^{-3}$ & $9.03 \times 10^{-2}$ & $1.27 \times 10^{-2}$ & $1.56 \times 10^{-1}$ \\
\hline Average pore diameter $(\AA)^{\mathrm{c}}$ & 20.32 & 22.47 & 20.23 & 32.93 \\
\hline Amount of complex $\left(\mathrm{mmol} \mathrm{g}^{-1}\right)^{\mathrm{d}}$ & - & - & 1.36 & 0.88 \\
\hline
\end{tabular}

\subsection{Characterization of Supported Catalysts}

Scanning electron microscope attached with energy dispersive X-ray (EDS, EDAX) dedector (SEM, Carl Zeiss Ultra Plus) was used to investigate the surface morphologies and elemental compositions of Dw-Cu and Sm-Cu after gold coating processes. The amount of $\mathrm{Cu}(\mathrm{tmen})(\mathrm{OH})\left(\mathrm{OH}_{2}\right)^{+}$bound to $\mathrm{Dw}$ and $\mathrm{Sm}$ was calculated from the elemental analysis were done using Vario III Elementar element analyzer.

\subsection{Kinetic Measurements}

In a typical reaction, the supported catalyst $(10 \mathrm{mg})$ was suspended in $4.75 \mathrm{~mL}$ of TAPS buffer ( $\mathrm{pH} 9.0)$ and incubated in a period of $10 \mathrm{~min} .0 .5 \mathrm{~mL}$ of the substrate stock solution in acetonitrile was added to the suspension containing the supported catalyst. At certain times, the suspension was centrifugated and 
the absorbance of $p$-nitrophenolate anion (NP) which is the product of hydrolytic reaction of the substrates in the supernatant was determined spectrophotometrically at $400 \mathrm{~nm}$. From the absorbance values of NP, its concentration was determined using an appropriate calibration curve of NP and the kinetics of the hydrolysis reactions were determined. Initial reaction rates (IRR) of the reactions were determined from NP concentration versus time (Figure 2, inset).

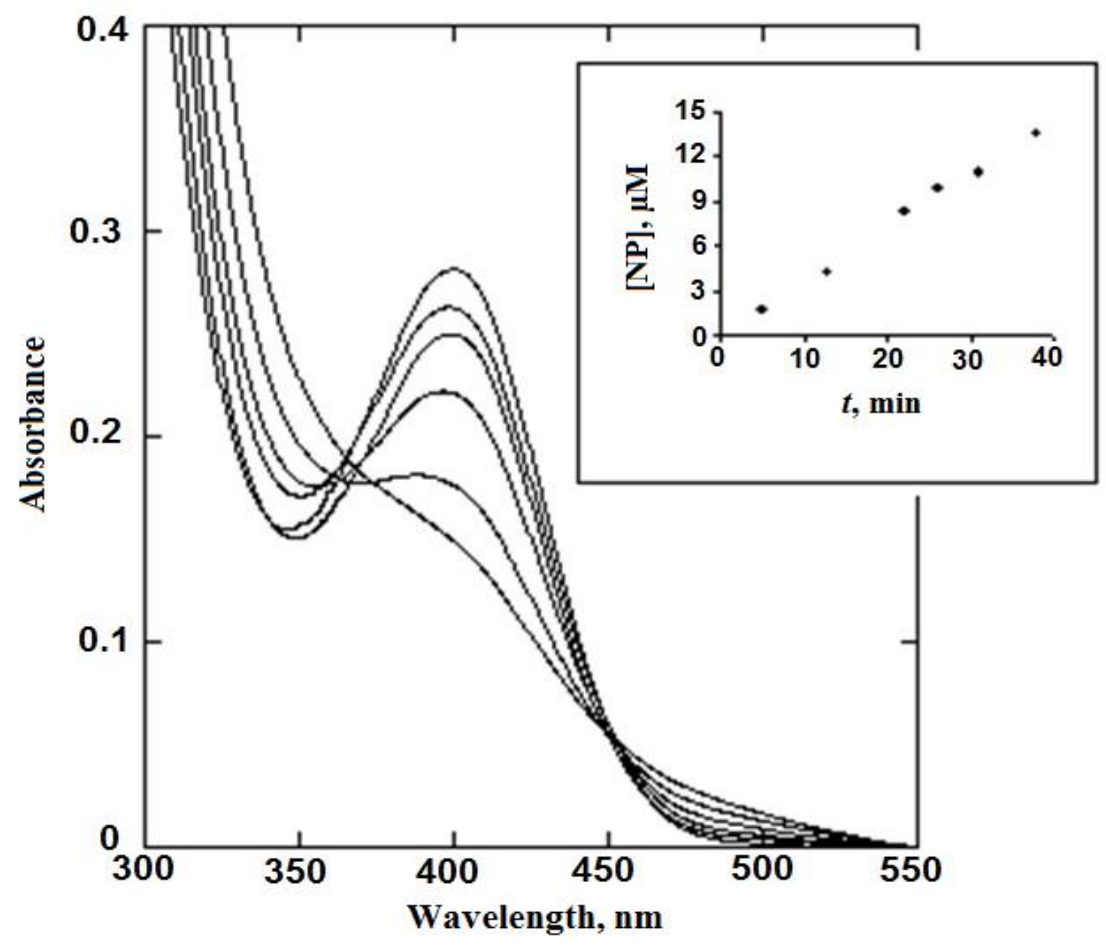

Figure 2. Increasing of NP absorbance with time for the hydrolysis of PO promoted by Dw-Cu and time dependence of the concentration of NP released from hydrolysis reaction (Inset). Reaction conditions: $\left[\mathrm{Cu}^{2+}\right]=1.36 \mathrm{mM},[\mathrm{PO}]=5 \times 10^{-4} \mathrm{M},[\mathrm{TAPS}]=5 \mathrm{mM}, \mathrm{pH}=9.0,25^{\circ} \mathrm{C}$

\section{RESULTS AND DISCUSSION}

\subsection{Characterization of Supported Catalysts}

SEM images and EDS spectra of the supported catalysts are shown in Figure 3a-d. The images revealed that $\mathrm{Sm}-\mathrm{Cu}$ had rough and porous surface character, while spherical morphology was observed for Dw$\mathrm{Cu}$. The presence of $\mathrm{Cu}$ in both supported catalyst was clearly seen from EDS results. Moreover, the amount of $\mathrm{Cu}(\mathrm{tmen})(\mathrm{OH})\left(\mathrm{OH}_{2}\right)^{+}$in $\mathrm{Dw}-\mathrm{Cu}$ and $\mathrm{Sm}-\mathrm{Cu}$ was calculated from the elemental analysis results as $0.88 \mathrm{mmol} / \mathrm{g}$ and $1.36 \mathrm{mmol} / \mathrm{g}$, respectively (see Table 1 ). 

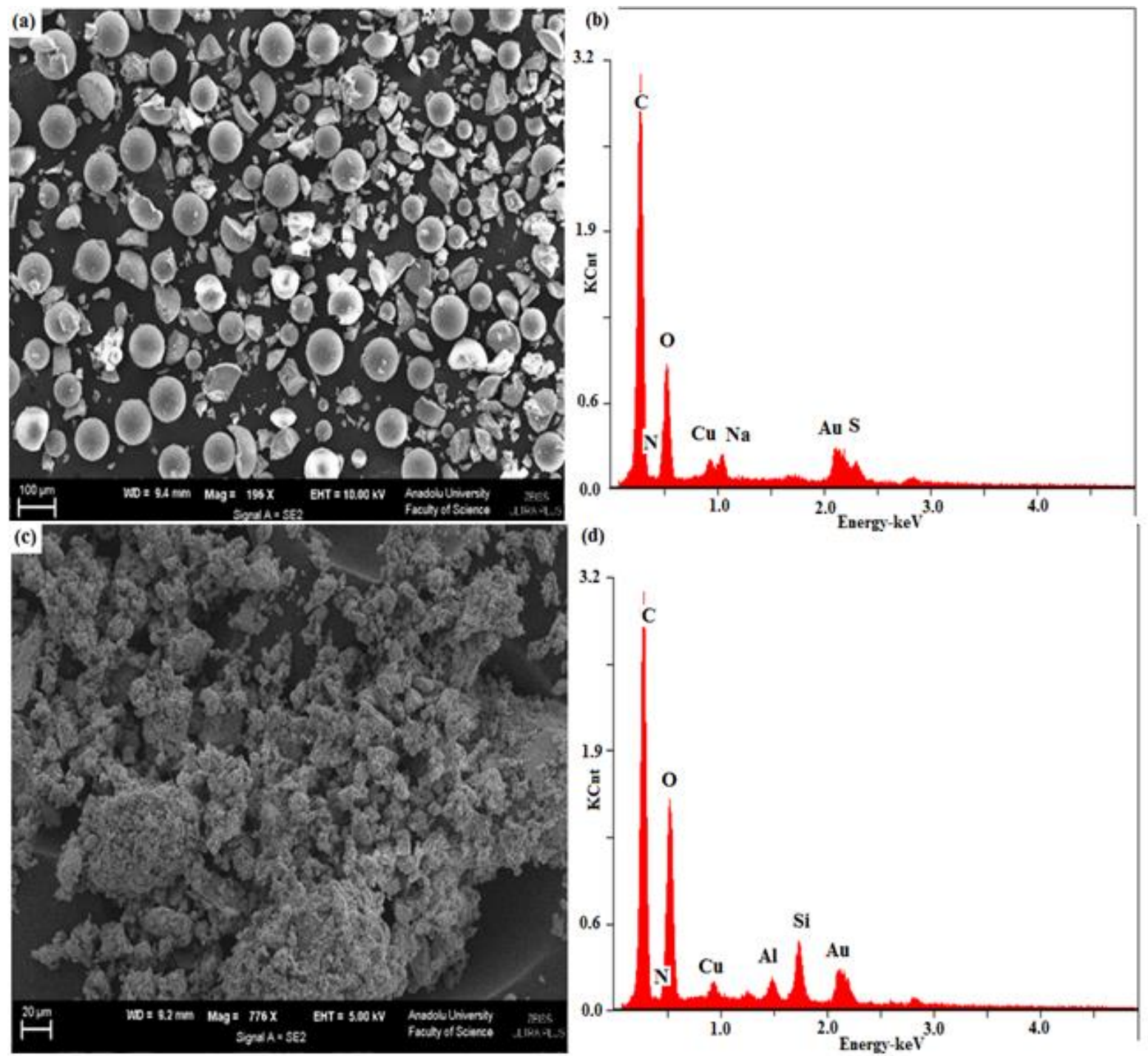

Figure 3. SEM images of (a) Dw-Cu and (c) $\mathrm{Sm}-\mathrm{Cu}$ and EDS spectra of (b) Dw-Cu and (d) $\mathrm{Sm}-\mathrm{Cu}$

\subsection{Kinetics of PO and PNPDPP Hydrolysis}

To evaluate the efficiency of $\mathrm{Dw}-\mathrm{Cu}$ and $\mathrm{Sm}-\mathrm{Cu}$ for the hydrolysis of PO and PNPDPP, kinetic investigations were carried out at $\mathrm{pH} 7.0,8.0,9.0$ and 9.5 at $25^{\circ} \mathrm{C}$. In previous works, authors have used pseudo-first-order kinetic model to evaluate the time dependency of organophosphate hydrolysis catalyzed by metal complexes and their polymer supported derivatives [27, 29, 30]. The rate equation of the hydrolysis of organophosphates such as PNPDPP and PO catalyzed by metal complexes in basic conditions can be given as:

$$
\begin{gathered}
\text { Rate }=\frac{-d[\text { Substrate }]}{d t} \\
\text { Rate }=k_{2}\left[\mathrm{Cu}(\text { tmen })(\mathrm{OH})\left(\mathrm{OH}_{2}\right)^{+}\right][\text {Substrate }]+k_{\mathrm{OH}}\left[\mathrm{OH}^{-}\right][\text {Substate }]
\end{gathered}
$$

In this rate equation, the terms $k_{2}\left[\mathrm{Cu}(\mathrm{tmen})(\mathrm{OH})\left(\mathrm{OH}_{2}\right)^{+}\right][$Substrate $]$and $k_{\mathrm{OH}}\left[\mathrm{OH}^{-}\right][$Substrate $]$represent the contributions of metal complex catalyzed and $\mathrm{OH}^{-}$catalyzed reactions on the total hydrolysis rate of substrate, respectively. At constant $\mathrm{Cu}(\mathrm{tmen})(\mathrm{OH})\left(\mathrm{OH}_{2}\right)^{+}$and $\mathrm{OH}^{-}$concentrations, these values become 
constant, then the rate of hydrolysis becomes linearly dependent only on the concentration of substrate (Eq. (3)).

$$
\text { Rate }=\left(k_{2}\left[\mathrm{Cu}(\text { tmen })(\mathrm{OH})\left(\mathrm{OH}_{2}\right)^{+}\right]+k_{O H}\left[\mathrm{OH}^{-}\right][\text {Substrate }]\right)=k_{\text {obs }}[\text { Substrate }]
$$

Under these conditions, the hydrolysis of substrates are first-order reaction. The integrated form of Eq. (3) is given below (Eq. (4)).

$$
\ln \left(\frac{[\text { Substrate }]}{[\text { Substrate }]_{0}}\right)=-k_{\text {obs }} t
$$

The plot of $\ln \left([\text { Substrate]/[ Substrate }]_{0}\right)$ against $t$ yields a straight line whose slope equals $-k_{\mathrm{obs}}$.

The pseudo-first-order kinetic plots for PO hydrolysis over a pH range of 7.0-9.5 are shown in Figure 4 and $k_{\mathrm{obs}}$ values for PO and PNPDPP hydrolysis are tabulated in Table 2. For both substrates, the values of $k_{\mathrm{obs}}$ increased with increasing $\mathrm{pH}$ and then decreased with its further increasing. The highest $k_{o b s}$ values were obtained with $\mathrm{Dw}-\mathrm{Cu}$ at $\mathrm{pH} 9.0$ for both substrate. When compared $k_{\text {rel }}$ values, the best efficiency in the hydrolysis of the substrates was achieved at $\mathrm{pH} 8.0 . k_{\text {obs }}$ values obtained at $\mathrm{pH} 8.0$ with Dw-Cu were $2.19 \times 10^{-4} \mathrm{~min}^{-1}$ for PO and $2.63 \times 10^{-3} \mathrm{~min}^{-1}$ for PNPDPP.

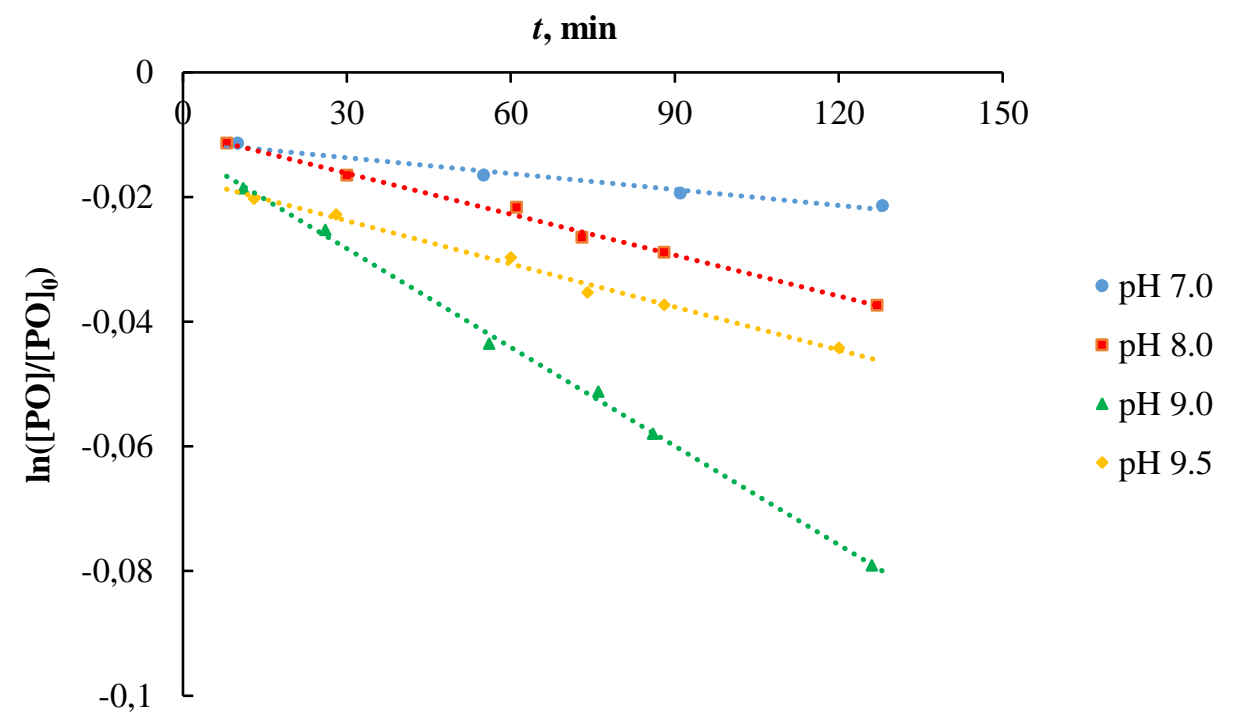

Figure 4. Plots of pseudo-first-order kinetics of hydrolysis of $\mathrm{PO}$ with $10 \mathrm{mg}$ of $\mathrm{Dw}-\mathrm{Cu}$ at $\mathrm{pH}$ 7.0, 8.0, 9.0 and 9.5. Reaction conditions: $\left[\mathrm{Cu}^{2+}\right]=1.36 \mathrm{mM},[\mathrm{PO}]=5 \times 10^{-4} \mathrm{M},[\mathrm{TAPS}]=5 \mathrm{mM}, 25^{\circ} \mathrm{C}$ 
Erdem / Anadolu Univ. J. of Sci. and Technology A-Appl. Sci. and Eng. 18 (3)-2017

Table 2. Pseudo-first-order rate constants for the hydrolysis of PO and PNPDPP at various $\mathrm{pH}$ values

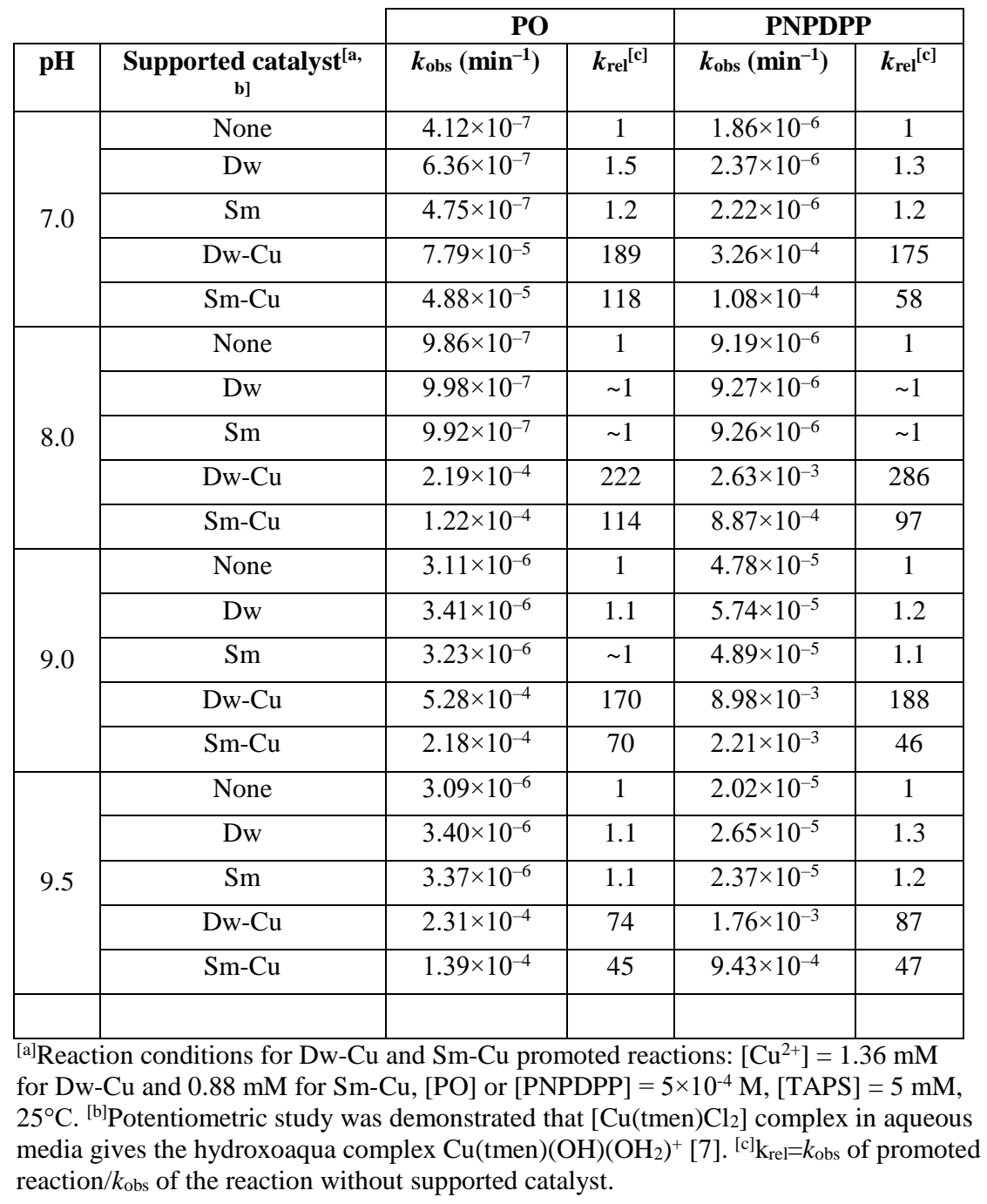

\subsection{Michaelis-Menten Kinetics of the Supported Catalysts}

Saturation kinetics for the hydrolysis of the substrates with $\mathrm{Dw}-\mathrm{Cu}$ and $\mathrm{Sm}-\mathrm{Cu}$ was observed. The effect of PO concentration on the initial rate for the hydrolysis of PO by the supported catalysts at $\mathrm{pH} 9$ and $25^{\circ} \mathrm{C}$ is shown in Figure 5. The non-linear curves revealed that reactions might follow Michaelis-Menten kinetics and the kinetic parameters for PO hydrolysis, $K_{M}$ and $I R R_{\max }$ were determined from the Lineweaver-Burk plot (Figure 5, related equation is Eq. 5).

$$
\frac{1}{I R R}=\frac{K_{M}}{I R R_{\max }} \frac{1}{[S]}+\frac{1}{I R R_{\max }}
$$

In this equation, $I R R_{\max }$ is the maximum reaction rate and $K_{M}$ is Michaelis constant which reflects the affinity of the supported catalyst towards the substrate. The lower $K_{M}$ value corresponds the higher affinity. $k_{\text {cat }}$ which is another important kinetic parameter was calculated by dividing $I R R_{\text {max }}$ by the $\mathrm{Cu}(\mathrm{II})$ concentration. For $\mathrm{PO}$ hydrolysis with $\mathrm{Dw}-\mathrm{Cu}, I R R_{\max }, K_{M}$ and $k_{\text {cat }}$ were found to be $1.20 \times 10^{-}$ ${ }^{6} \mathrm{M} \mathrm{min}^{-1}, 2.19 \mathrm{mM}$ and $8.85 \times 10^{-4} \mathrm{~min}^{-1}$, respectively. While for $\mathrm{Sm}-\mathrm{Cu}$, the corresponding values were $4.05 \times 10^{-7} \mathrm{M} \mathrm{min}{ }^{-1}, 6.64 \mathrm{mM}$ and $4.60 \times 10^{-4} \mathrm{~min}^{-1}$. These parameters were also obtained for the hydrolysis of PNPDPP with same supported catalysts and all of them are summarized in Table 3. 


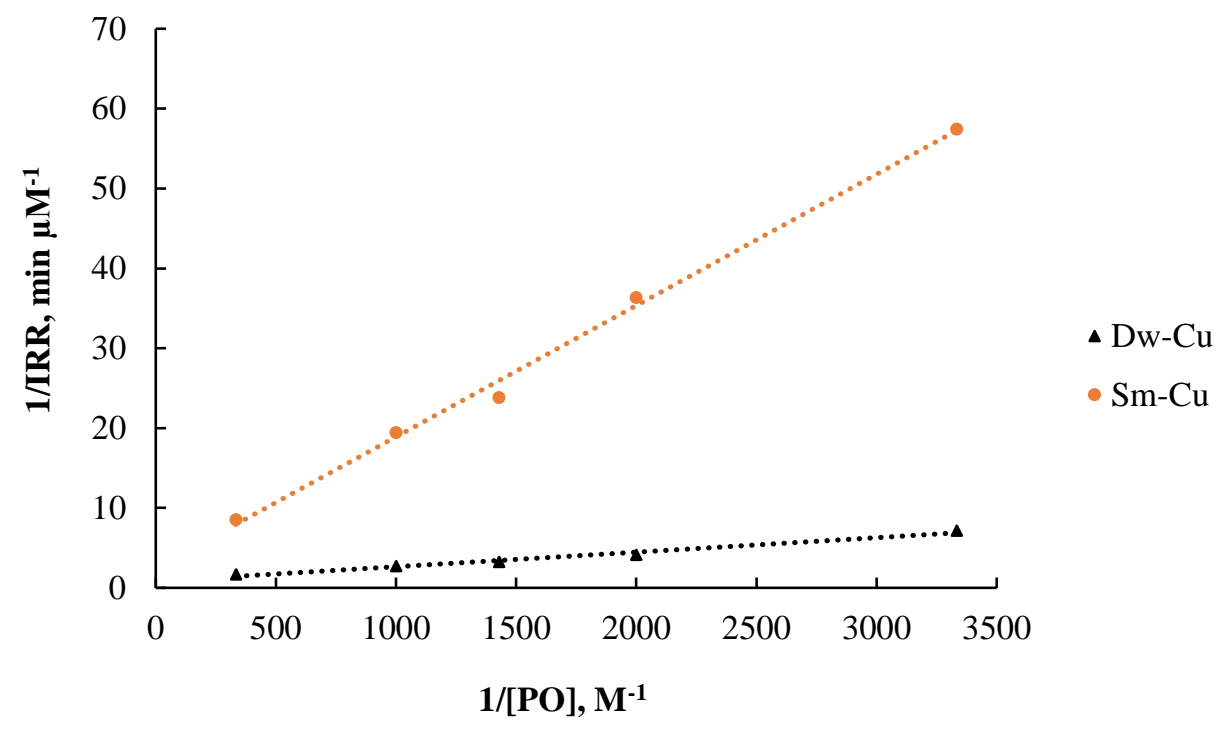

Figure 5. Lineweaver-Burk plots for substrates promoted by $\mathrm{Dw}-\mathrm{Cu}$ and $\mathrm{Sm}-\mathrm{Cu}$. Reaction conditions: $\left[\mathrm{Cu}^{2+}\right]=1.36$ $\mathrm{mM}$ for Dw-Cu and $0.88 \mathrm{mM}$ for $\mathrm{Sm}-\mathrm{Cu}$, [Substrate] $=0.3-3.0 \mathrm{mM},[\mathrm{TAPS}]=5 \mathrm{mM}, \mathrm{pH}=9.0,25^{\circ} \mathrm{C}$

Table 3. Michaelis-Menten kinetic parameters for the hydrolysis of PO and PNPDPP at $\mathrm{pH} 9.0^{\text {[a] }}$

\begin{tabular}{|l|l|l|l|l|}
\hline Substrate & $\begin{array}{l}\text { Supported } \\
\text { catalyst }\end{array}$ & $\mathbf{I R R}_{\mathbf{m a x}}, \mathbf{M} \mathbf{~ m i n}^{\mathbf{1}}$ & $\mathbf{K}_{\mathbf{m}}, \mathbf{m M}$ & $\boldsymbol{k}_{\text {cat }}{ }^{[\mathbf{b}]}, \mathbf{~ m i n}^{\mathbf{- 1}}$ \\
\hline PO & Dw-Cu & $1.20 \times 10^{-6}$ & 2.19 & $8.85 \times 10^{-4}$ \\
\hline PO & Sm-Cu & $4.05 \times 10^{-7}$ & 6.64 & $4.60 \times 10^{-4}$ \\
\hline PNPDPP & Dw-Cu & $27.86 \times 10^{-6}$ & 1.11 & $2.05 \times 10^{-2}$ \\
\hline PNPDPP & Sm-Cu & $10.79 \times 10^{-6}$ & 1.46 & $1.23 \times 10^{-2}$ \\
\hline
\end{tabular}

${ }^{[\mathrm{a}]}$ Reaction conditions: See Fig. 5 footnotes. ${ }^{[\mathrm{b}]} k_{\mathrm{cat}}=\mathrm{IRR}_{\max } /\left[\mathrm{Cu}^{2+}\right]$

\subsection{Effect of Temperature on the Hydrolysis}

It is well known that the temperature is one of the most important factor to affect the reaction rate. In this study, some experiments were carried out for the temperature range from $25^{\circ} \mathrm{C}$ to $65^{\circ} \mathrm{C}$ to investigate the effect of temperature on the hydrolysis of PO and PNPDPP. Pseudo-first-order kinetic plots of substrates at different temperatures are given in Figure 6. As expected, $k_{o b s}$ values for the hydrolysis of both substrate were increased by increasing the temperature. The activation energy of the reaction $\left(E_{\mathrm{a}}\right)$ was also calculated from each of these constants at different temperature values. The plots of $\ln k_{o b s}$ vs. 1/T were drawn (Figure 7) using Arrhenius equation to determine $E_{\mathrm{a}}$. 
a)

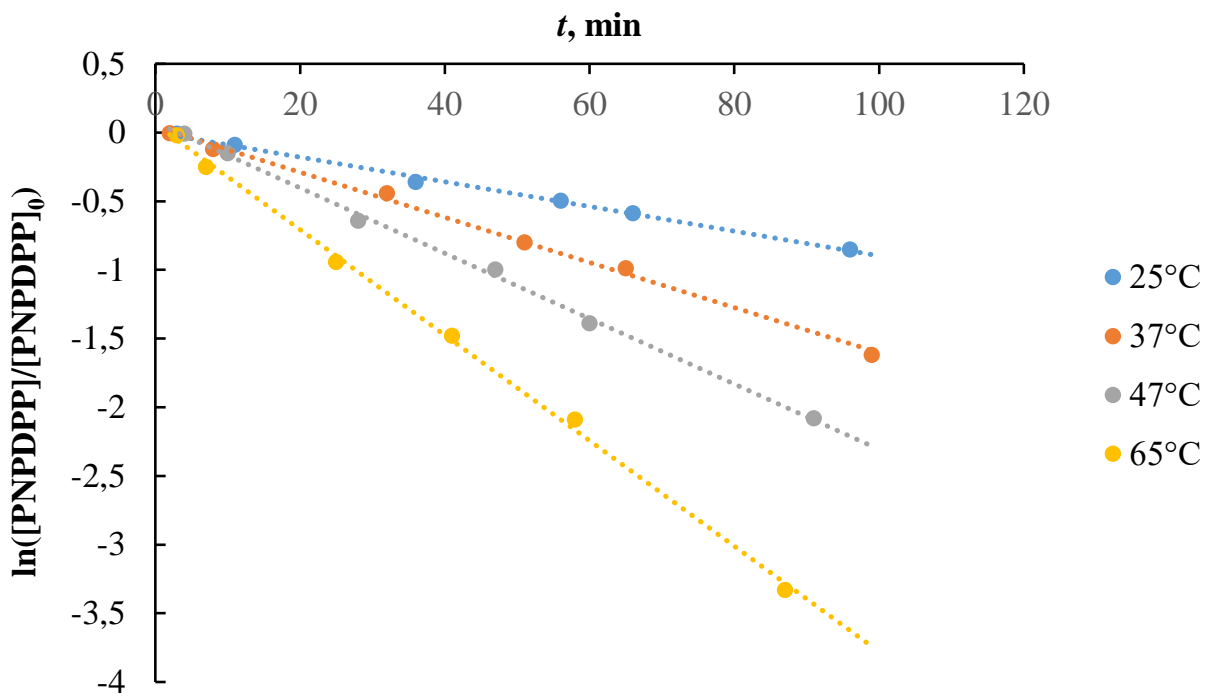

b)

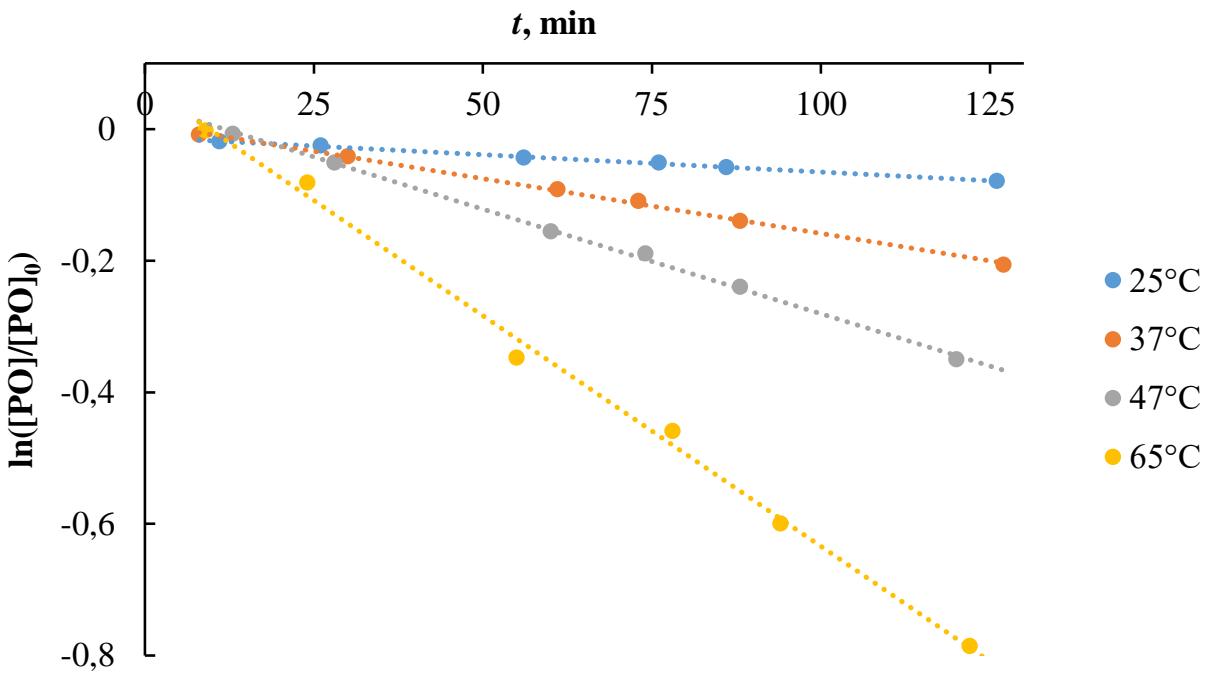

Figure 6. Plots of pseudo-first-order kinetics of a) PNPDPP and b) PO hydrolysis with $10 \mathrm{mg}$ of Dw-Cu at various temperatures. Reaction conditions: $\mathrm{pH}=9.0,\left[\mathrm{Cu}^{2+}\right]=1.36 \mathrm{mM}$, [substrate $]=5 \times 10^{-4} \mathrm{M}$, [TAPS $]=5 \mathrm{mM}$ 
Erdem / Anadolu Univ. J. of Sci. and Technology A-Appl. Sci. and Eng. 18 (3) - 2017

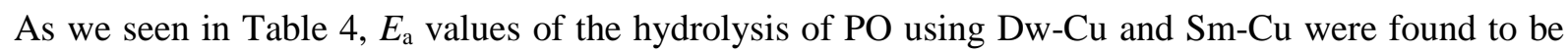
$54.6 \mathrm{~kJ} \mathrm{~mol}^{-1}$ and $61.8 \mathrm{~kJ} \mathrm{~mol}^{-1}$, respectively.

Table 4. The rate constants and $E_{\mathrm{a}}$ values for hydrolysis of substrates at different temperatures ${ }^{[a]}$

\begin{tabular}{|c|c|c|c|c|}
\hline Substrate & $\begin{array}{c}\text { Supported } \\
\text { catalyst }\end{array}$ & $\mathbf{T},{ }^{\circ} \mathbf{C}$ & $k_{\mathrm{obs}}, \min ^{-1}$ & $E_{\mathrm{a}}, \mathrm{kJ} \mathrm{mol}^{-1}$ \\
\hline \multirow{8}{*}{ PNPDPP } & \multirow{4}{*}{$\mathrm{Dw}-\mathrm{Cu}$} & 25 & $8.98 \times 10^{-3}$ & \multirow{4}{*}{30.8} \\
\hline & & 37 & $1.64 \times 10^{-2}$ & \\
\hline & & 47 & $2.38 \times 10^{-2}$ & \\
\hline & & 65 & $3.84 \times 10^{-2}$ & \\
\hline & \multirow{4}{*}{$\mathrm{Sm}-\mathrm{Cu}$} & 25 & $2.21 \times 10^{-3}$ & \multirow{4}{*}{35.9} \\
\hline & & 37 & $2.65 \times 10^{-3}$ & \\
\hline & & 47 & $4.91 \times 10^{-3}$ & \\
\hline & & 65 & $1.10 \times 10^{-2}$ & \\
\hline \multirow{8}{*}{$\mathrm{PO}$} & \multirow{4}{*}{$\mathrm{Dw}-\mathrm{Cu}$} & 25 & $5.28 \times 10^{-4}$ & \multirow{4}{*}{54.6} \\
\hline & & 37 & $1.66 \times 10^{-3}$ & \\
\hline & & 47 & $3.18 \times 10^{-3}$ & \\
\hline & & 65 & $7.01 \times 10^{-3}$ & \\
\hline & \multirow{4}{*}{$\mathrm{Sm}-\mathrm{Cu}$} & 25 & $2.18 \times 10^{-4}$ & \multirow{4}{*}{61.8} \\
\hline & & 37 & $6.82 \times 10^{-4}$ & \\
\hline & & 47 & $1.50 \times 10^{-3}$ & \\
\hline & & 65 & $3.85 \times 10^{-3}$ & \\
\hline
\end{tabular}

[TAPS] $=5 \mathrm{mM}, \mathrm{pH} 9.0$

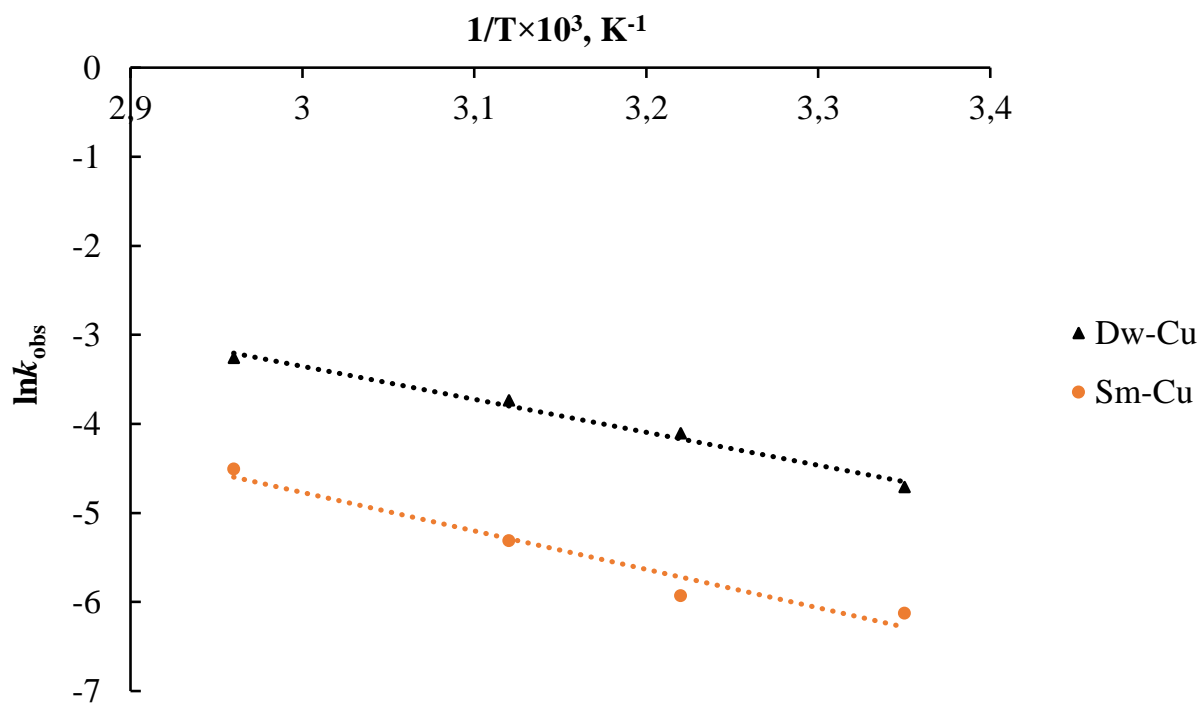

Figure 7. Arrhenius plots for $E_{\mathrm{a}}$ calculations of PNPDPP hydrolysis

\section{CONCLUSIONS}

The present investigation was aimed to the determination of the efficiency of smectite- and Dowexsupported $\mathrm{Cu}(\mathrm{tmen})(\mathrm{OH})\left(\mathrm{OH}_{2}\right)^{+}$for the cleavage of PO and PNPDPP. These systems are very efficient to promote phosphate hydrolysis. The results indicated that both supported catalyst showed a significant rate enhancement and $\mathrm{Dw}-\mathrm{Cu}$ was found to be more effective than $\mathrm{Sm}-\mathrm{Cu}$ for the hydrolysis of the substrates. The following conclusions can also be suggested: 
$\checkmark$ As expected, $k_{o b s}$ values for the hydrolysis of both substrate were increased by using supported catalyst due to decreasing the activation energy of the reactions.

$\checkmark$ The efficiency of the supported catalysts are strongly affected by $\mathrm{pH}$. Dw-Cu and $\mathrm{Sm}-\mathrm{Cu}$ displayed a 222- and 114-fold rate enhancement, respectively, relative to reactions without supported catalyst at $\mathrm{pH} 8.0$.

$\checkmark$ Although the BET surface area of Sm-Cu $94.60\left(\mathrm{~m}^{2} \mathrm{~g}^{-1}\right)$ was higher than that of Dw-Cu (12.51 $\mathrm{m}^{2} \mathrm{~g}^{-1}$ ) (Table 1), Dw-Cu showed higher efficiency for the hydrolysis of substrates at all kinetic experiments. These findings could be attributed to a higher complex bounding capacity of Dw$\mathrm{Cu}$ which is $1.36 \mathrm{mmol}$ per gram of the support while $0.88 \mathrm{mmol}$ is for $\mathrm{Sm}-\mathrm{Cu}$.

$\checkmark$ Detailed kinetic studies of the hydrolysis reactions were evaluated using Michaelis-Menten plots. It was seen that $k_{\mathrm{cat}} / \mathrm{K}_{\mathrm{m}}$ values of the supported catalysts towards PNPDPP was higher than that of PO. Also, Dw-Cu was more efficient for the hydrolysis of $\mathrm{PO}$ compared to $\mathrm{Sm}-\mathrm{Cu}$ by a factor of 5.8. Similarly, for PNPDPP hydrolysis this value was determined as 2.2.

$\checkmark$ It was clearly seen that the efficiency of supported catalysts increases, when the activation energy of the hydrolysis reactions decreases.

\section{REFERENCES}

[1] Toy ADF, Walsh EN. Phosphorus Chemistry in Everyday Living. 2nd ed. Washington, DC, USA: American Chemical Society, 1987.

[2] Morales-Rojas H, Moss RA. Phosphorolytic reactivity of o-iodosylcarboxylates and related nucleophile. Chem Rev 2002; 102: 2497-2521.

[3] Quin LD. A Guide to Organophosphorus Chemistry. New York, NY, USA: Wiley, 2000.

[4] Yang YC, Baker JA, Ward JR. Decontamination of chemical warfare agents. Chem Rev 1992; 92: 1729-1743.

[5] Munro NB, Ambrose KR, Watson AP. Toxicity of the organophosphate chemical warfare agents GA, GB, and VX-implications for public protection. Environ Health Perspect 1994;102: 18-38.

[6] Gallo MA, Lawryk NJ. Organic Phosphorus Pesticides. The Handbook of Pesticide Toxicology. San Diego, CA, USA: Academic Press, 1991.

[7] Mersal GAM, Ibrahim MM. Solution studies of tris(2-benzylaminoethyl)amine complexes of zinc(II) and copper(II): The catalytic hydrolysis of toxic organophosphate. Cr Chim 2012; 15: 336345 .

[8] Tafesse F. Hydrolysis of nerve agent simulants by synergistic effects of tetraminecobalt(III) and microemulsions. Inorg Chim Acta 1998; 269: 287-291.

[9] Scrimin P, Ghirlanda G, Tecilla P, Moss RA. Comparative reactivities of phosphate ester cleavages by metallomicelles. Langmuir 1996; 12: 6235-6241.

[10] Hafiz, AA. Metallosurfactants of $\mathrm{Cu}$ (II) and $\mathrm{Fe}(\mathrm{III})$ complexes as catalysts for the destruction of paraoxon. J Surfactants Deterg 2005; 8: 359-363. 
[11] Hay RW, Govan N. The $\left[\mathrm{CoN}_{4}(\mathrm{OH})\left(\mathrm{OH}_{2}\right)\right]^{2+}\left(\mathrm{N}_{4}=\right.$ trpn, cyclen and tren $)$ promoted hydrolysis of the phosphotriester 2,4-dinitrophenyl diethyl phosphate. Transit Metal Chem 1998; 23: 721-725.

[12] Moss RA, Alwis KW, Bizzigotti GO. Ortho-iodosobenzoate-catalyst for the micellar cleavage of activated esters and phosphates. J Am Chem Soc 1983; 105: 681-682.

[13] Katritzky AR, Duell BL, Durst HD, Knier BL. Substituted o-iodoso- and o-iodoxybenzoic acids. Synthesis and catalytic activity in the hydrolysis of active phosphorus esters and related systems. $\mathbf{J}$ Org Chem 1988; 53: 3972-3978.

[14] Mackay RA, Longo FR, Knier BL, Durst HD. Iodosobenzoate catalyzed hydrolysis of 4nitrophenyl diphenyl phosphate in a CTAB microemulsion. J Phys Chem 1987; 91: 861-864.

[15] Ford WT, Yu H. Rapid hydrolysis of p-nitrophenyl diphenyl phosphate catalyzed by oiodosobenzoate in cationic latexes. Langmuir 1991; 7: 615-616.

[16] Erdem M, Turk H. Preparation of cationic latexes with different length alkyl groups on their quaternary ammonium ions and their use as supports for IBA catalyst in the hydrolysis of PNPDPP. React Funct Polym 2008; 68: 321-331.

[17] Bunton CA, Robinson LB. Micellar effects upon the reaction of p-nitrophenyl diphenyl phosphate with hydroxide and fluoride ions. J Org Chem 1969; 34: 773-780.

[18] Manfredi AM, Willian D, Eduardo HW, Silva BV, Pinto AC, Souza BS, Nome F. Rapid cleavage of phosphate triesters by the oxime 2-(hydroxyimino)-N-phenyl-acetamide. J Phys Org Chem 2016; 29: 600-603.

[19] Dumas DP, Caldwell SR, Wild JR, Raushel FM. Purification and properties of the phosphotriesterase from pseudomonas-diminuta. J Biol Chem 1989; 264: 19659-19665.

[20] Chae MY, Postula JF, Raushel FM. Stereospecific enzymatic-hydrolysis of phosphorus-sulfur bonds in chiral organophosphate triesters. Bioorg Med Chem Lett 1994; 4: 1473-1478.

[21] Yamazaki T, Yilmaz E, Mosbach K, Sode K. Towards the use of molecularly imprinted polymers containing imidazoles and bivalent metal complexes for the detection and degradation of organophosphotriester pesticides. Anal Chim Acta 2001; 435: 209-214.

[22] Erdem M, Say R, Ersoz A, Denizli A, Turk H. Biomimicking, metal-chelating and surfaceimprinted polymers for the degradation of pesticides. React Funct Polym 2010; 70: 238-243.

[23] Hegg EL, Burstyn JN. Toward the development of metal-based synthetic nucleases and peptidases: a rationale and progress report in applying the principles of coordination chemistry. Coord Chem Rev 1998; 173: 133-165.

[24] Courtney RC, Gustafson RL, Westerback SJ, Hyytiainen H, Chaberek SC, Martell AE. Metal chelate compounds as catalysts in the hydrolysis of isopropylmethylphosphonofluoridate and diisopropylphosphorofluoridate. J Am Chem Soc 1957; 79: 3030-3036.

[25] Hartshorn CM, Deschamps JR, Singh A, Chang EL. Metal-chelator polymers as reactive adsorbents for organophosphate hydrolysis. React Funct Polym 2003; 55: 219-229. 
[26] Blacker NC, Findlay PH, Sherrington DC. Synthesis of Cu-II-complexed polymers and use as catalysts in the hydrolytic decontamination of Sarin nerve agent. Polym Advan Technol 2001; 12: 183-196.

[27] Bukowski MR, Hile BL, Figurelli A, Hotham I, Maurer, MK. Insights into heterogeneous phosphodiester hydrolysis using a simple hydrogel-based copper(II)-imidazole catalyst. Inorg Chim Acta 2011; 370: 405-410.

[28] Tafesse F. Hydrolysis of nerve agent simulants by synergistic effects of tetraminecobalt(III) and microemulsions. Inorg Chim Acta 1998; 269: 287-291.

[29] Chandrasekhar V, Athimoolam A, Srivatsan SG, Sundaram PS, Verma S, Steiner A, Zacchini S, Butcher R. Pyrazolylcyclotriphosphazene containing pendant polymers: Synthesis, characterization, and phosphate ester hydrolysis using a $\mathrm{Cu}(\mathrm{II})$-metalated cross-linked polymeric catalyst. Inorg Chem 2002; 41: 5162-5173.

[30] Srivatsan SG, Verma S. Nucleobase-containing metallated polymeric resins as artificial phosphodiesterases: Kinetics of hydrolysis, $\mathrm{pH}$ dependence, and catalyst recycling. Chem Eur J 2001; 7: 828-833. 